\title{
Challenges and Threats Faced in 2020 by International Logistics Companies Operating on the Polish Market
}

\author{
Halina Brdulak ${ }^{1}$ iD and Anna Brdulak ${ }^{2, *(D)}$ \\ 1 Department of International Management, SGH Warsaw School of Economics, 02-554 Warszawa, Poland; \\ halina.brdulak@sgh.waw.pl \\ 2 Faculty of Computer Science and Management, Wrocław University of Science and Technology, \\ 50-370 Wrocław, Poland \\ * Correspondence: anna.brdulak@pwr.edu.pl
}

check for updates

Citation: Brdulak, H.; Brdulak, A. Challenges and Threats Faced in 2020 by International Logistics Companies Operating on the Polish Market. Sustainability 2021, 13, 359. https:// doi.org/10.3390/su13010359

Received: 26 October 2020 Accepted: 29 December 2020 Published: 3 January 2021

Publisher's Note: MDPI stays neutral with regard to jurisdictional clai$\mathrm{ms}$ in published maps and institutional affiliations.

Copyright: $\odot 2021$ by the authors. Licensee MDPI, Basel, Switzerland. This article is an open access article distributed under the terms and conditions of the Creative Commons Attribution (CC BY) license (https:// creativecommons.org/licenses/by/ $4.0 /)$.
Abstract: The main aim of the article is to present an analysis of the current challenges and threats to the Transport-Forwarding-Logistics (TFL) sector in Poland based on internet surveys. The aim of the article is, therefore, to investigate whether the challenges and threats described by managers in a two-year perspective are related to sustainable development. This area primarily concerns external conditions. On the other hand, in the surveys that were the subjects of the analyses, a section related to sustainable development in economic, environmental, and social terms was identified, in which the focus was primarily on the internal activities of the company. The article has a practical dimension. The article analyzes comments from managers posted in an internet survey. They constitute a separate part of the questionnaire, which mainly concerns financial indicators and other factors that determine the company's competitiveness. Half of the respondents are companies with foreign capital, and half-Polish companies. Based on the comments over a three-year period with over sixty managers from logistics companies in Poland, an analysis of the most important challenges that companies in the logistics industry have to face in the near future was presented. The survey is a part of a broader research project that has been conducted in the form of a quantitative survey among approximately sixty TFL companies for twenty-five years on an annual basis. The results of the survey are supplemented with an attempt to analyze the current situation in 2020 related to the impending economic recession as a result of the coronavirus disease 2019 (COVID-19) threat. The surveyed companies constitute a significant part of the TFL market in Poland. Thus, they are the benchmark for the entire industry. Therefore, an important value of the presented analysis is the up-to-date research, as well as the ability to relate the results and developed scenarios to the entire TFL sector.

Keywords: logistics challenges; logistics management; logistics companies; TFL sector; risk management; COVID-19; sustainable development; supply chain management

\section{Introduction}

The latest complete data of the Central Statistical Office (GUS) on Gross domestic product (GDP) for 2017 show that the Transport-Forwarding-Logistics (TFL) sector generated 5.8\% of GDP. In 2017, it was Polish złoty (PLN) 115.3 billion [1]. Therefore, it can be clearly seen that it plays an important role in the economy in terms of added value and revenue generated for the state budget. Its condition is perceived as an indicator of the condition of the economy in total. The industry's results show the first signs of positive or negative economic trends. Other factors that affect the TFL industry include legal regulations (national, international), international political conditions, trade agreements, and megatrends. The above information shows, on the one hand, the significant impact of the TFL industry on the state of the entire economy, and on the other hand, the importance of the opinion of TFL managers regarding the prospects for action. Factors that may affect managers' perceptions in 2020 are presented below. 
The TFL industry entered into 2020 facing the prospect of many constraints. A large unknown remains Brexit, which took place on 31 January, and has resulted in uncertainties in customs policy, generating downtime. There are still no final decisions to be made as to how the UK will leave the European Union. An additional problem is the weakening of European GDP, following primarily the outbreak of coronavirus disease 2019 (COVID-19). According to Eurostat data, as of the end of July 2020, the euro zone economy decreased by $12.1 \%$ (11.9\% in the European Union, EU) in the second quarter compared to the first quarter of 2020 [2]. Statistical data from 15 October shows that the economy of the European Union will decrease overall by $8.3 \%$ in 2020 . Poland's GDP is forecast to shrink by $4.4 \%$ [3]. This is the biggest decrease since 1995, when the EU statistical office started to present aggregated data. Data on GDP level forecasts are constantly verified due to the unknown effects of the second wave of the pandemic. Therefore, the above information may only be valid at the time of publication. The announced changes in European law, such as the introduction of the "Mobility Package" [4] and the unclear situation in China, resulting primarily from the impact of the pandemic on the Silk Road [5] also make the transport industry face numerous challenges [6]. In addition to these difficulties, are the ongoing coronavirus threat and the resulting social and economic problems. These factors make the industry look at 2020 with uncertainty, anticipating that the coming years will be a period of intensive change.

Due to high economic and social uncertainties and dynamic changes in markets on a global scale, analyses based on cyclical industry surveys are of particular value. Such a study is one on challenges and threats for the TFL industry, with particular emphasis on issues related to sustainable development. It is a supplement to the research project, ongoing for twenty-five years, conducted by one of the co-authors, Prof. H. Brdulak.

To fully investigate a research problem, the following research questions should be asked:

1. What are the challenges for the entire TFL industry and to what extent are they related to sustainable development?

2. What are the threats that TFL industry representatives have observed and to what extent do they affect sustainable development?

The purpose of the article is to provide an answer to the above questions, based on a unique analysis, which has been carried out during the period of 2018-2020.

The analysis period (three years) was adopted by the authors due to the disclosure of factors that could affect the scope of the respondents' statements. These are primarily: the weakening economic situation in European Union countries, announcements of the introduction of the mobility package, announcements of the adoption of the Green Deal by the European Union (the program was adopted in July 2020), and the need to adapt to environmental requirements. An additional factor with a very strong impact on the economy is the coronavirus. The effects of this factor will be long-term and will become more pronounced in forthcoming years [6]. The main reason for considering the three-year research period is the formulation of the question in the survey. Both challenges and threats are perceived in a two-year perspective. Managers, in reference to the above topic in 2018, indicated their expectations in 2020.

\section{Characteristics of TFL Industry in Poland}

Due to the specificity and heterogeneous nature of the TFL market in Poland compared to other markets in the European Union countries, the Polish TFL market was characterized before the presentation of the research results. The market of companies representing the suppliers of TFL is very fragmented in Poland. On the one hand, there are entities representing large global corporations, and on the other hand-micro, small, and medium enterprises, which most often represent the Polish capital $[7,8]$. The significant share of global logistics companies on the Polish market is primarily related to the fact that these companies are looking for opportunities to compete. Poland, as a country geographically located in the center of Europe, with a fairly good linear and point infrastructure, as well 
as a large sales market, is attractive from the cost point of view for global companies. An additional advantage of Poland is the availability of qualified management staff. Thus, after Poland joined the European Union in 2004, there was a very dynamic development of representative offices of global operators in this market. Their competitive advantage over Polish companies mainly concerns size, advanced management tools, and a higher degree of digitization. However, during the course of the past sixteen years there have been significant changes, which can be reduced to two key factors; by progressing market consolidation (the take-over of medium-sized Polish companies by global operators) and the take-over of key management positions by Polish managers in global companies. The dynamics of TFL market development, measured by the growth of revenues year-on-year, was high during these years. In 2019, the revenues of the companies participating in the ranking increased by $12 \%$, similar to the previous year. Based on GUS statistics in 2019, which take into account passenger and freight transport by all modes of transport, the revenues from the sale of services in all transport entities were higher by $8.7 \%$ in comparison with 2018 [8]. This means that the growth rate was two or three times higher than the growth rate of the GDP. Currently, over sixty-thousand entities operating in the TFL sector are registered. The vast majority of them, about $95 \%$, are microenterprises (up to nine persons), often family enterprises, which mostly deal with road transport. In recent years, there has been a trend to expand the scope of operations of such companies by undertaking commercial or repair activities. This allows for the distribution of risk when one of the activities is in the phase of a downturn. Microenterprises are most often subcontractors for larger entities, which offer freight forwarding and operate in the field of logistics. In this case, from the point of view of risk management, some companies made the decision to create a hybrid business model in which the company can act both for a larger principal, but also has its own customers for whom it provides services.

Thus, the market is divided into several global companies, mostly logistics companies, which are principals for a large number of small transport companies. Road transport is still the dominant branch of transport, as in the European Union [9]. Large companies with revenues exceeding one billion PLN per year are most often represented by global foreign corporations in Poland. They represent mainly German, French, and Dutch capital. The last decade has seen an increase in the management efficiency of Polish companies, measured by the profitability index. They are increasingly led by Polish managers who have already gained management experience in foreign logistics companies. However, there is still a noticeable advantage of companies with foreign capital among companies that indicate logistics as their main activity and companies with Polish capital in forwarding and transport. Analyzing financial indicators, it is evident that activities related to logistics (including contact logistics) are characterized by higher margins than forwarding or transport activities. In regards to the business models used by global logistics operators, both their own resources and external suppliers are currently used. Pure outsourcing models, popular in the previous decade, are now used to a lesser extent. This is due to the increase in uncertainty about the economic situation and the political environment compared to the beginning of the first decade of the 21st century.

\section{Literature Review}

In order to identify a research gap and systematize available knowledge, the authors conducted an analysis of available scientific publications in the thematic area of this article. Due to the global reach and prestige in the scientific world, the research was covered by the Scopus database. After typing the following keywords: "transport and freight and logistics and challenges," a total of eighty-eight publications were received: nine from the year 2020, thirty-two from 2019, and twenty-three from 2018. The authors narrowed the area of exploration to three years for two reasons. Firstly, due to the time range of the analyses presented in the article, covering the years 2018-2020. Secondly, due to the dynamic nature of the described phenomenon, subject to constant changes. 
After the quantitative analysis, it was considered worthwhile to investigate the content of the identified items. The articles published this year can basically be divided into two thematic areas: challenges in urban logistics [10-12] and intermodal transport issues or industry perspectives on selected issues, e.g., India [13], the Silk Road [14], or challenges in the context of emerging economies [15]. The issue of risk related to supply chains is discussed in the publication focused on identification and proposal of a set of seven risk factors that drive the risks associated with the Belt and Road initiative. Supply Chain risk and Belt and Road initiative models help to build a theory of risk management in supply chains [16]. An interesting approach is presented by B. Nitsche [17]. Describing the Belt and Road Initiative (BRI) case, the author refers to the barrier and development paths for the entire logistics network from a global perspective. Gea, Dollarb i Yuc [18] analyze institutions and participation in global value chains, which in the context of the challenge of shortening supply chains seems to be one of the key elements. The Belt and Road Initiative is also referred to in the publication by Chana et al. [19]. It concerns innovation, areas identified as one of the challenges in 2020. The authors of Wang et al. write about current trends in transportation research in the context of the BRI [20].

In the context of the conducted research, it is also worth paying attention to the issues of sustainable development. This subject was discussed numerous times, from slightly different angles. Publications from earlier years, 2018-2019, mostly focus on ecology in transport and sustainable development. The authors of Beškovnik and Golnar write about the elimination of barriers in the BRI and Baltic-Adriatic Corridor (BAC) projects in relation to the pollution level produced from transport means [21]. This problem seems to be particularly important due to the growing awareness of customers and the resulting increase in expectations of responsible actions taken by logistics operators. A systemic approach to decisions made for urban freight transport, taking into account the elements of sustainable development, is proposed by Nenni, Sforza and Sterle [22]. It is a good complement to the research presented in this article.

Problems in a sustainable supply chain are well analyzed in the example presented in the article by Shareef et al. [23] based on the Bangladesh case study.

It is also worth mentioning the challenges of supply chains, widely presented in the literature. They are the insufficient flow of information [24], efficiently supply chain management [25] or the last mile problem [26,27].

On the basis of the conducted literature studies, a research gap is clearly outlined in the form of a study of challenges and threats to the TFL market presented in the Results section. The authors additionally focused on the Polish market. The narrowing of the research area resulted in its in-depth analysis.

Considering all of the above, it can therefore be concluded that this type of research has not been conducted thus far. It gives rise to the conclusion that the presented approach is innovative and the research is unique.

\section{Research Model Description}

\subsection{General Description}

The study on challenges and threats to the TFL industry is a supplement to the cyclical quantitative survey that has been carried out annually for the past 25 years. The main part of the project covers over sixty companies. The results are presented in the form of TFL ranking. The companies participating in the TFL ranking are the main market players. They operate on the Polish market and represent Polish, mixed, and foreign capital. They are primarily companies whose main activity is based on road transport and logistics. However, almost all companies also offer other services, based on rail, intermodal, air, and sea transport. In addition, they are also indicated as activities of warehousing services (contract logistics), customs, and courier services. However, road transport plays a dominant role in the structure of revenues, as in most European Union countries. Therefore, the statements of managers are dominated by issues related to the challenges of road transport. 
Later in the article, the results of the supplementary research will be presented, focusing on the open-ended question analysis of high-level managers representing the TFL industry. From their perspective, they were asked to indicate the biggest challenges facing the industry. To better understand the presented considerations, the authors first offer the assumptions of the research model. They then move on to the analysis of data from the two preceding years, i.e., 2018 and 2019. This is due to the fact that the 2018 study included a question about the challenges for the next two years, i.e., 2019 and 2020. Similarly in 2019, when respondents identified challenges and threats for 2020 and 2021. The results of the 2020 study were also added to the analysis, which gave a picture of the impact of COVID-19 on the perception of the prospects for the TFL industry for the next two years (2021 and 2022).

This approach provides an opportunity to address more broadly the challenges currently faced by the industry, as well as to review previous business assumptions. This approach to the problem offers an added value to the analysis.

\subsection{Research Model Assumptions}

The survey covers enterprises that provide transport, forwarding, and logistics services in the field of goods. The survey does not cover companies that provide passenger transport services. Information is collected through a quantitative questionnaire available on the website. Every year, before launching the survey among companies, the questionnaire is double-checked by both the author and the research company, along with information collected and statistically analyzed by the research company.

An important factor in the success of the entire study is the author's constant contact with a representative from the company's side, supervising the study and already experienced in verifying the credibility of completed questionnaires. Responses to individual questions are examined in terms of correlation, which has been obtained on the basis of many years of observation. In the case of finding "disturbances", the answers are verified by direct telephone contact with the respondent. However, recent changes taking place on the market show that the correlation thus far (based on historical data) is not always accurate. Therefore, it is essential to cross-check data on an ongoing basis.

In addition to quantitative information (mainly financial), the company also indicates the services it offers on the market, the certificates it holds and the main area of its operations (the criterion is the turnover). For the last five years, additionally, the respondents have also indicated the main challenges and threats anticipated in the next two years in the form of open comments.

The answers to open-ended questions are categorized. Categorization is a process in which the responses are put into certain response categories (more general response groups). Multiple responses are typically made from open-ended questions. Thus, the responses that appear are assigned to more general categories in which the responses are semantically similar. This approach is presented in the article in a form of collective tables.

The given analysis covers the period 2018-2020. It presents subjective opinions on a two-year market perspective. The questions in the survey were formulated as follows: what challenges do you see for the TFL industry in Poland in the next two years? What are the threats and dangers for the TFL industry in Poland in the next two years?

In addition to the survey, the authors also analyzed the statements of the participants in the debate. It is carried out on a regular basis with the participation of five or six presidents or high-level managers in the office of the economic daily, in which the ranking is published (also on an annual basis). The debate is moderated by the co-author of this study and a journalist.

The aim of the presented research is to determine how the priorities from the industry point of view have changed over the years, with particular emphasis on issues related to sustainable development. 


\section{Results and Discussion}

\subsection{The Biggest Challenges for the TFL Industry for 2018}

The greatest challenges faced by the industry in the next two years were identified in 2018 as the improvement of technical infrastructure, automation, and technology development, economic, and social changes, legal regulations, the possibility of entering other markets, organizational changes, and development of intermodal transport.

Table 1 presents the challenges for the next two years, identified by TFL industry managers in 2018 [28]. The following table, as Table 2 in which the risks are presented, is based on the results of the survey and conclusions from the debate. The order of the mentioned areas is deliberate and reliant on the number of indications offered by managers.

Table 1. Challenges in 2018 (own analysis).

\begin{tabular}{|c|c|}
\hline Challenges 2018 & Detailed Description \\
\hline Infrastructure & $\begin{array}{l}\text { Vehicle development, improvement of roads, } \\
\text { expansion of seaports. }\end{array}$ \\
\hline Technological environment: innovation & Innovation, Artificial Intelligence (AI), blockchain. \\
\hline Technological environment: digitization & The development of Internet commerce. \\
\hline Macroeconomic environment & $\begin{array}{l}\text { Increase in societal prosperity, general economic } \\
\text { growth in the European Union (EU), territorial } \\
\text { expansion, entrance into new markets, } \\
\text { potential-growth exports from Poland (PL), Silk } \\
\text { Road as a direction with potential for Poland, } \\
\text { development of EU economies, China, Germany, } \\
\text { development of intermodal transport: rail } \\
\text { transport in PL and outside, development of } \\
\text { maritime transport. }\end{array}$ \\
\hline Legal environment & $\begin{array}{l}\text { Brexit, changes in transport-related regulations in } \\
\text { EU member states, increase in transport rates. }\end{array}$ \\
\hline Organizational environment & Consolidation, industry standards, offshoring. \\
\hline
\end{tabular}

When analyzing the challenges presented in Table 1, it can be noticed that legal factors, as well as related issues of increasing the share of intermodal transport and rail transport, constitute the area of managers' interest. These elements influence the environmental aspects of sustainable development. Such external factors also include the improvement of road infrastructure and the use of new technologies. The above factors contribute to reducing the carbon footprint. However, some, such as the increase in exports or offshoring, may lead to increased negative environmental impact, if they are not accompanied by optimization strategies.

Due to dynamic changes in the macroeconomic and legislative environment, the biggest threats faced by the TFL industry in 2018 were the workforce deficit, the policy of the European Union member states, including Brexit and discussions on the Mobility Package, and the poor condition of road infrastructure (Table 2).

The phenomenon of the workforce deficit results primarily from the dynamic economic growth, stimulating the creation of new jobs in the economy, unfavorable demographic trends, and changes in pension regulations. The respondents indicated that this is the problem they encounter most often. There is not only a shortage of drivers, but also a shortage of a specialized workforce, which includes warehouse and office workers. Technological changes, in the opinion of company representatives, create not only challenges, but also pose a real threat related to the frequent application of solutions, which omit traditional logistics operators. 
Table 2. Threats in 2018 (own analysis).

\begin{tabular}{cr}
\hline Threats $\mathbf{2 0 1 8}$ & Detailed Description \\
\hline Organizational environment & $\begin{array}{c}\text { Lack of drivers, lack of workforce, ongoing difficulty in } \\
\text { obtaining qualified staff, both office and warehouse workers } \\
\text { and drivers, technological changes-Increasing solutions that } \\
\text { ignore traditional logistics operators, reduction of rates, } \\
\text { leading to deterioration of service quality. }\end{array}$ \\
\hline
\end{tabular}

Unfavorable legal regulations, EU regulations protectionism at the European level, introduction of minimum wages by successive EU member states, lack of reaction on the part of the Polish government to the problems of carriers, increasing

Legal environment bureaucracy, formal and legal obstacles imposed by Western countries, protectionism of the "old EU" countries towards the "new EU" countries, interference in the Polish market of "third countries", changeability of Polish law, limitations for Polish carriers in Europe-MiLOG in Germany, Loi Macron in France and recently in Italy.

Blockade of markets, nepotism, trade wars, the situation of German economy, low unemployment and rising wage expectations, exchange rate differences in international transport, rising labor costs, economic slowdown of EU and PL, Mobility Package, rising transport costs, saturated labor

Macroeconomic environment market in the industry, uncertain value of PLN, higher risk of currency exchange rate fluctuations against USD and EUR, and decreasing margins on foreign sales, changes related to retirement age, problems with city logistics, rising fuel prices, political situation in Poland, political situation in Europe (Russia vs. EU vs Turkey), political factors hampering trade with Russia and Ukraine

Infrastructure Traffic congestion, decreasing road and parking space capacity.

As shown in Table 2, the number of threats perceived by managers in the next two years is significantly greater than the number of challenges. They focus primarily on issues related to international trade and progressive regulations in trade, which limit free access to other markets, and on political factors. From the point of view of sustainable developmentone can pay attention to the issue of deteriorating quality of roads and congestion. These factors negatively affect the carbon footprint. However, the problems related to access to cities mentioned by managers have a positive impact on the environment, which has already been measured in cities that have introduced restrictions. A significant threat is the unavailability of employees, both drivers and qualified warehouse and office workers. The above-mentioned issues of a social nature derive from regulations concerning the professional and developmental prospects. It is an important element of sustainable development, which can be described as "decent work", which is also adequately remunerated, according to the competences held. This is one of the goals listed among the 17 United Nations Sustainable Development Goals [29].

\subsection{The Biggest Challenges for the TFL Industry for 2019}

Analyzing the challenges and threats that have been put forward by managers in particular years, it can be observed that there are notable changes in comparison to the year 2018. Table 3 presents the challenges that managers foresee for the TFL industry in Poland, based on the analysis of a survey and statements in an expert debate in 2019 [30]. 
Table 3. Challenges in 2019 (own analysis).

\begin{tabular}{cc}
\hline Challenges 2019 & Detailed Description \\
\hline Technological environment: innovation & $\begin{array}{c}\text { Industry 4.0, automation, robotization, electrical cars, } \\
\text { car hybrids, drones, long road trains. }\end{array}$ \\
\hline $\begin{array}{c}\text { Technological environment: } \\
\text { digitization }\end{array}$ & $\begin{array}{c}\text { Development of Internet commerce, increased use of } \\
\text { mobile devices, trading platforms, logistic platforms, } \\
\text { modern warehouse management systems (WMS). }\end{array}$ \\
& $\begin{array}{c}\text { Elimination of restrictions on trade with Russia, new } \\
\text { regulations to encourage the development of rail } \\
\text { and intermodal transport, industry consolidation } \\
\text { (Mergers \& Acquisitions, M\&A), Brexit (reallocation } \\
\text { of companies from the UK to the European Union) }\end{array}$ \\
\hline Infrastructure & $\begin{array}{c}\text { Modernization of railway infrastructure, } \\
\text { construction of the Central Communication Port, } \\
\text { investments in the Małaszewicze border crossing, } \\
\text { transport nodes and road terminals. }\end{array}$ \\
\hline
\end{tabular}

Economic growth in the EU and the continuing high rate of GDP growth in Poland, Poland's good position as a provider of TFL services to the EU market, increase in transit through Poland, Poland

Macroeconomic environment

Organizational environment as a storage facility for global companies, increase in consumption, geographical location of Poland at the crossroads of trade routes, development of the automotive industry, increase in domestic distribution, development of the Silk Road and cooperation with China.

Development of multi-channel sales, new business models (proximity retail), development of industry standards, horizontal cooperation in a limited scope (competition-logistics company-courier company).

In 2019, the focus, in terms of challenges, shifted to issues related to the development of new technologies. Automation and robotization, which are important elements of Industry 4.0, and electric cars, are used to improve logistics processes. The greater use of digital technologies and warehouse management software have similar effects. These activities lead, in the long run, to reducing the workload, reducing the level of wastage associated with downtime, or shortening the time of carrying out specific activities. The released potential of employees who are not forced to perform monotonous and repetitive work can be used for more creative work. This is in line with goals 8 and 9 of the UN Global Compact and Sustainable Development Goals: decent work and economic growth and industry innovation and infrastructure. Among the additional challenges, there is also the possibility of cooperation between competitors. This means the possibility of better use of resources, not only within the enterprise, but also in the supply chain. Moreover, the above-mentioned measures have a positive impact on the environment, inter alia, through better use of the cargo space of trucks, which is currently used in about $60-70 \%$ capacity. As a result, the number of cars necessary to handle orders will decrease, and thus the carbon footprint will decrease. However, the challenges related to the macro-environment may pose a threat to sustainable development, especially related to the expected increase in the role of Poland as a transit country. In the absence of regulations in this regard, the number of vehicles traveling on Polish roads may significantly escalate, which will result in increasing pollution, further congestion and noise. The possibility of limiting this scenario is related to the greater use of rail and intermodal transport, which was also reflected in the comments of managers.

Table 4 presents the threats that managers foresee for the TFL industry in Poland, based on the analysis of a survey and statements in the expert debate in 2019. 
Table 4. Threats in 2019 (own analysis).

\begin{tabular}{c} 
Threats 2019 \\
Detailed Description \\
\hline Legal environment \\
protecting its own market and limiting the access of \\
non-resident carriers of particular countries, in particular \\
the Mobility Package, instability of the Polish legal system, \\
Brexit border blockages, increase in administrative \\
procedures; increase in fiscal burdens (taxes, costs of ship \\
owners' adaptation to new standards of sulfur content in \\
marine fuel, increase in energy prices), lack of clear \\
procedures when employing foreigners, restriction of access \\
to city centers, regulations concerning \\
environmental protection.
\end{tabular}

Recession, decrease in consumption, increase in fiscal burdens on enterprises, greater connection between politics and business-negative impact, unstable political situation in Poland and in the world, high dependence of Poland on the macroeconomic situation in the world, increase in

Macroeconomic environment protectionism, competition from the Silk Road to the sea road, unstable situation on the sea freight market, decrease in the inflow of financial resources from EU funds.

Shortage of skilled workers; shortage of drivers, warehouse workers; increased competition in the industry and outside the industry (Uber), the possibility of taking over the Polish TFL market by carriers from Russia, Belarus, Ukraine, new

Organizational environment business models (cost pressure, price pressure), increase in wages, interception by global shipping line organizations, taking over the competence of freight forwarders, self-service logistics introduced by global players in the online trading market

\begin{tabular}{cc}
\hline Infrastructure & $\begin{array}{c}\text { Delays in road modernization (road and rail transport), } \\
\text { insufficient infrastructure (linear and spot). }\end{array}$ \\
\hline Technological environment & $\begin{array}{r}\text { Lack of funds for process automation, increase in IT } \\
\text { spending with limited resources. }\end{array}$ \\
\hline
\end{tabular}

In reference to the threats mentioned by managers in 2019, attention is focused on the introduction of the mobility package, which changes the conditions of operation of TFL companies on the European market. Polish carriers, thanks to the competitive advantage associated with lower labor costs and a high level of flexibility, are well positioned on the European market in international transport. Recommendations regarding working time, minimum wage rates, and driver's rest in good conditions, were not strictly followed by carriers from Poland, as in the case of other Eastern European countries. As a result, this limited the ability of TFL companies from Western Europe to compete, which had specific standards related to occupational hygiene. The introduction of the mobility package by regulation resulted in the leveling of competition conditions and was in line with the goals of sustainable development (goal no. 8). However, this made it necessary to take into account the cost increases related to the new regulations. Opponents of the mobility package believe that certain provisions regarding the necessity to return the carrier's trucks to the country of registration will increase environmental pollution. They are motivated by the necessity to drive an empty vehicle, and thus the increase in the number of vehicles on the road. In the statements of managers, concerns will be observed related to the deterioration of the financial situation of their companies, which are the result of the introduced fiscal solutions, but also the upcoming recession. The inability to freely use employees from other countries, in the absence of qualified employees in Poland, is still a serious threat. The conditions for doing business are changing, and the competition from outside the industry requires companies to develop better working 
conditions for employees, thus implementing goal no. 8 of the UN Global Compact and Sustainable Development Goals. Restricting entry to cities, another factor in this analysis, is the implementation of goal no. 11: sustainable cities and communities. However, it is perceived as a priority-threat to managers, as potentially contributing to increased costs. The issues of financial liquidity in this industry are a very important factor in making decisions, with a relatively low level of margins (according to own research, at the level of $2-3 \%$ ).

\subsection{Challenges for TFL in 2020}

Analyzing the challenges and threats indicated by managers in 2020 (the research was carried out in April 2020), the risks, resulting mainly from the loss of liquidity and the consequences of bankruptcy, economic recession and changes in the processes of international trade flows (intensified protectionist tendencies, closing borders as a result of the pandemic), have become much more apparent than in previous years. Although the level of uncertainty about the future is increasing among managers, at the same time the areas relating to innovation and the Industry 5.0 trend are still regarded as challenges. The dynamic change in the distribution channels used in commerce, resulting in doubling e-commerce transactions, has resulted in a significant increase in the importance of city logistics, "last mile" logistics, and business to customer (B2C) relations. On the side of challenges and threats, consolidation of the industry also often appears (more often as a challenge), as well as a new type of outsourcing, which can be described as "sharing outsourcing" (term coined by the authors). By giving certain areas of their activity to professional, specialized entities, the companies do not want to lose control over them and come up with an indirect solution-co-control. Tables 5 and 6 present in detail the statements of managers on the basis of the analysis of the survey (the debate took place in June 2020) and interviews conducted by the authors with industry representatives [31].

Table 5. Challenges in 2020 (own analysis).

\begin{tabular}{|c|c|}
\hline Challenges 2020 & Detailed Description \\
\hline $\begin{array}{l}\text { Organizational } \\
\text { environment }\end{array}$ & $\begin{array}{l}\text { Accelerated consolidation of the TFL market, increased demand for } \\
\text { warehousing services and "city" warehouses, increased demand for } \\
\text { rail and intermodal services, "last mile" logistics, outsourcing on the } \\
\text { basis of joint control, development of multi-channel and omni-channel } \\
\text { sales, demand for premium services and dedicated solutions (3PL, } \\
\text { 4PL), alternative drive vehicles, long road trains, increased availability } \\
\text { of workforce, decreased pressure on wages, inter-branch integration, } \\
\text { development of contract logistics. }\end{array}$ \\
\hline $\begin{array}{l}\text { Technological } \\
\text { environment }\end{array}$ & $\begin{array}{l}\text { Dynamic development of e-commerce, digitization, automation, new } \\
\text { technologies, fulfilment, development of own transport and trade } \\
\text { platforms, storage systems integrated with customer sales systems. }\end{array}$ \\
\hline $\begin{array}{l}\text { Macroeconomic } \\
\text { environment }\end{array}$ & $\begin{array}{l}\text { Shortening of the supply chain, relocation of part of production to } \\
\text { Europe and Poland, established position of Polish carriers and TFL } \\
\text { companies on the European market, increase in demand for TFL B2C } \\
\text { services, favorable location of Poland at the crossroads of trade routes, } \\
\text { increase in importance of the Silk Road and Poland-China trade, } \\
\text { development of new markets }\end{array}$ \\
\hline Infrastructure & Improving the quality of road and rail infrastructure. \\
\hline legal environment & $\begin{array}{l}\text { Deferral of changes in road transport regulation in the } \\
\text { European Union. }\end{array}$ \\
\hline
\end{tabular}


Table 6. Threats in 2020 (own analysis).

\begin{tabular}{|c|c|}
\hline Threats 2020 & Detailed Description \\
\hline $\begin{array}{c}\text { Macroeconomic } \\
\text { environment }\end{array}$ & $\begin{array}{l}\text { Recession, economic crisis, decrease in production and consumption, } \\
\text { increase in unemployment, inflation, decrease in liquidity, company } \\
\text { bankruptcy, consolidation, isolationism, protectionism, restriction of } \\
\text { free movement of goods across borders, decrease in international } \\
\text { exchange, increase in environmental charges, road tolls, taxes, } \\
\text { exchange rate fluctuations, increase in energy prices, Brexit, } \\
\text { lengthening of supply chains, increase in competition from TFL } \\
\text { companies from the East (Russia, Ukraine, Belarus), high dependence } \\
\text { of the economy on the European Union market, uncertain political } \\
\text { situation, decrease in import from China. }\end{array}$ \\
\hline $\begin{array}{l}\text { Organizational } \\
\text { environment }\end{array}$ & $\begin{array}{l}\text { Notable consolidation in the industry, acquisitions of smaller and } \\
\text { weaker companies, increase in bankruptcies and bankruptcies in the } \\
\text { TFL industry, lack of professional drivers, qualified employees (office, } \\
\text { warehouses workers, also rail transport workers), increase in } \\
\text { competition, decrease in liquidity among customers (payment } \\
\text { deferrals), shorter supply chains, access to shipping containers } \\
\text { (uneven geographical distribution), increase in costs, decrease in } \\
\text { profitability, development of intermodal transport (displaces road } \\
\text { transport) - change in the share of individual branches in freight } \\
\text { transport, expansion of ship owner activities }\end{array}$ \\
\hline Legal environment & $\begin{array}{l}\text { Formal and legal obstacles imposed by Western European countries on } \\
\text { Eastern European TFL companies, mobility package, legal restrictions } \\
\text { related to the pandemic. }\end{array}$ \\
\hline $\begin{array}{l}\text { Technological } \\
\text { environment }\end{array}$ & $\begin{array}{l}\text { Development of e-commerce and decrease in demand for transport } \\
\text { from distribution centers to stationary sales points, development of } \\
\text { freight exchanges, new technologies requiring financial investments. }\end{array}$ \\
\hline Infrastructure & Railway infrastructure. \\
\hline
\end{tabular}

From the interviews with managers, the greatest challenges for the industry in 2020 seem to be, among others, digitization and technological development, shortening of supply chains as well as the changes in the legal environment in the field of European law. Thus, challenges related to the organizational environment and new technologies dominate this study. As has been shown before, these challenges fit into the concept of sustainable development, especially in goals 9 (industry, innovation and infrastructure), 11 (sustainable cities and communities), and 13 (climate action). The threats most frequently mentioned by the industry did not include the threat of a developing pandemic of COVID19. Perhaps this is due to the fact that the survey was conducted in the first half of 2020, when the situation was uncertain and the changes were dynamic. The main threats that are perceived by managers are related to the macroeconomic situation resulting from the recession and pandemic. The risk of bankruptcy and increasing competition from the Baltic countries are increasing, so financial factors are also dominant. In this situation, fear of takeovers is also growing. It can be concluded that in regards to growing concerns related to financial liquidity, other issues, also related to sustainable development, become less important. The comments of managers show greater pessimism than in previous studies, and the speed of digitization and the growth of e-commerce are perceived as a threat, especially for traditional companies. In this case, goal 13: climate action is not commented on by managers.

When analyzing the challenges and threats that have been presented in the above tables over the last three years, the issues related to sustainable development do not appear directly among the factors mentioned. This means that the analyzed companies do not treat the above areas as significant yet, factored also by the lack of financial instruments at the state level that enforce specific actions in this area. However, some of the areas related to sustainable development appear on both sides (challenges and threats) of this analysis. These are the issues of regulations regarding intermodal transport and support for rail 
transport as being greener, as well as the mobility package, in which issues related to driver rest and changes in costs related to drivers' salaries are discussed in the transport sector in Poland.

Among other factors, there are also issues related to entry-restriction to cities in the context of increasing pollution of urban areas [32] and shortening of the supply chains. The shortening of supply chains is related to the increase in uncertainty regarding supplies mainly from Asian countries, as well as the development of the local purchasing trend in the younger generation. In the subsequent analyzed years, it can also be noticed that the issues of digitization and the associated automation and robotization are becoming increasingly important.

The above factors affect sustainable development by changing working conditions, reducing the burden on employees, but also the need to develop own competences, which may increase the technological gap between younger and older employees.

The summary characteristics of the challenges (Table 7) and threats (Table 8), as a part of the challenge, identified in 2018, 2019, and 2020 respectively in the horizon of two years ahead are presented in the tables below.

An interesting area in the case of challenges is the legal environment. It is clear that in both 2018 and 2019, the identified challenge was Brexit. After that time, attention was redirected to dealing with deferral changes in road transport regulation in the European Union. Relations with China and the development of the Silk Road are still important among the macroeconomic challenges. It is also worth paying attention to the shortening of supply chains emerging in 2020 in the context of the threat of the coronavirus pandemic.

The above areas in Table 8 presenting the consolidated threats in the next two years remain mostly similar over the analyzed years. In 2020, among the threats, appears the risk of bankruptcy of enterprises in the TFL industry, and as a result, an increase in market competition. Concerns are related to the lack of financial liquidity in the customerenterprise relationship and the increase in prices. The threat of a pandemic and the related restrictions are significantly lowering the mood in the TFL sector.

As previously mentioned, the survey also included a specific area that concerned the sustainable development strategy [14] within the analyzed enterprises. The results of this section are presented below in order to complete a picture of sustainability in the TFL industry. The authors examined the extent to which the sustainable development strategy is implemented by TFL enterprises in the context of three areas: ecology, ethics, and economy.

Reporting of the sustainable development policy, and thus making it public on the company's websites, is practiced by $20 \%$ of the surveyed companies. Sixty percent of enterprises prepare a report of this type, but do not make it public. Generally, reports are prepared by large foreign corporations, mostly according to Global Reporting Initiatives (GRI) standards, and an external consulting company helps in their preparation. These companies also prepare ethical codes. It is interesting from the management point of view to look at the process of creating codes of ethics itself, whether all stakeholders are involved in the process, in particular employees, suppliers and customers, or whether such a code has been defined by the management board. Subsequently, the method of publication of the code and its availability, the so-called good and bad practices based on the particular examples. 
Table 7. Challenges in 2020—various time-horizon perspective (own analysis).

\begin{tabular}{|c|c|c|c|}
\hline Challenge Categories in 2020 & Declared in 2018 & Declared in 2019 & Declared in 2020 \\
\hline Infrastructure & $\begin{array}{l}\text { Vehicle development, } \\
\text { improvement of roads, } \\
\text { expansion of seaports. }\end{array}$ & $\begin{array}{c}\text { Modernization of railway } \\
\text { infrastructure, construction of the } \\
\text { Central Communication Port, } \\
\text { investments in the Małaszewicze } \\
\text { border crossing, transport nodes and } \\
\text { road terminals }\end{array}$ & $\begin{array}{l}\text { Improving the quality of road and } \\
\text { rail infrastructure. }\end{array}$ \\
\hline $\begin{array}{l}\text { Technological environment: } \\
\text { Innovation }\end{array}$ & Innovation, AI, blockchain. & $\begin{array}{l}\text { Industry } 4.0, \text { automation, robotization, } \\
\text { electrical cars, car hybrids, drones, } \\
\text { long road trains. }\end{array}$ & New technologies fulfilment. \\
\hline $\begin{array}{l}\text { Technological environment: } \\
\text { Digitization }\end{array}$ & $\begin{array}{l}\text { The development of Internet } \\
\text { commerce. }\end{array}$ & $\begin{array}{l}\text { Development of Internet commerce, } \\
\text { increased use of mobile devices, } \\
\text { trading platforms, logistic platforms, } \\
\text { modern warehouse management } \\
\text { systems (WMS). }\end{array}$ & $\begin{array}{l}\text { Dynamic development of } \\
\text { e-commerce, digitization, } \\
\text { automation, development of own } \\
\text { transport and trading platforms, } \\
\text { storage systems integrated with } \\
\text { customer sales systems. }\end{array}$ \\
\hline Macroeconomic environment & $\begin{array}{l}\text { Increase in society's wealth, } \\
\text { general economic growth in } \\
\text { the EU, territorial expansion, } \\
\text { entering other markets, } \\
\text { potentially growing exports } \\
\text { from PL, Silk Road as a } \\
\text { direction with potential for } \\
\text { Poland, development of EU } \\
\text { economies, China, Germany, } \\
\text { development of intermodal } \\
\text { transport: rail transport in PL } \\
\text { and outside, development of } \\
\text { maritime transport. }\end{array}$ & $\begin{array}{l}\text { Economic growth in the EU and the } \\
\text { continuing high rate of GDP growth } \\
\text { in Poland, Poland's good position as a } \\
\text { provider of TFL services to the EU } \\
\text { market, increase in transit through } \\
\text { Poland, Poland as a storage facility for } \\
\text { global companies, increase in } \\
\text { consumption, geographical location of } \\
\text { Poland at the crossroads of trade } \\
\text { routes, development of the } \\
\text { automotive industry, increase in } \\
\text { domestic distribution, development of } \\
\text { the Silk Road and cooperation } \\
\text { with China. }\end{array}$ & $\begin{array}{l}\text { Shortening of the supply chain, } \\
\text { relocation of part of production to } \\
\text { Europe and Poland, established } \\
\text { position of Polish carriers and TFL } \\
\text { companies on the European market, } \\
\text { increase in demand for TFL B2C } \\
\text { services, favorable location of } \\
\text { Poland at the crossroads of trade } \\
\text { routes, increase in importance of the } \\
\text { Silk Road and Poland-China trade, } \\
\text { development of new markets. }\end{array}$ \\
\hline Legal environment & $\begin{array}{l}\text { Brexit, changes in } \\
\text { transport-related regulations } \\
\text { in EU member states, increase } \\
\text { in transport rates. }\end{array}$ & $\begin{array}{l}\text { Elimination of restrictions on trade } \\
\text { with Russia, new regulations to } \\
\text { encourage the development of rail } \\
\text { and intermodal transport, industry } \\
\text { consolidation (M\&A), Brexit } \\
\text { (relocation of companies from the UK } \\
\text { to the European Union). }\end{array}$ & $\begin{array}{l}\text { Deferral of changes in road } \\
\text { transport regulation in the } \\
\text { European Union. }\end{array}$ \\
\hline Organizational environment & $\begin{array}{l}\text { Consolidation, industry } \\
\text { standards, offshoring. }\end{array}$ & $\begin{array}{l}\text { Development of multi-channel sales, } \\
\text { new business models (proximity } \\
\text { retail), development of industry } \\
\text { standards, horizontal cooperation in a } \\
\text { limited scope (competition-logistics } \\
\text { company-courier company). }\end{array}$ & $\begin{array}{l}\text { Accelerated consolidation of the } \\
\text { TFL market, increased demand for } \\
\text { warehousing services and "city" } \\
\text { warehouses, increased demand for } \\
\text { rail and intermodal services, "last } \\
\text { mile" logistics, outsourcing on the } \\
\text { basis of joint control, development } \\
\text { of multi-channel and omni-channel } \\
\text { sales, demand for premium services } \\
\text { and dedicated solutions (3PL, 4PL), } \\
\text { alternative drive vehicles, long road } \\
\text { trains, increased availability of } \\
\text { workforce, decreased pressure on } \\
\text { wages, inter-branch integration, } \\
\text { development of contract logistics. }\end{array}$ \\
\hline
\end{tabular}


Table 8. Threats in 2020-various time-horizon perspective (own analysis).

\begin{tabular}{ccc}
\hline $\begin{array}{c}\text { Threats Categories in } \\
\mathbf{2 0 2 0}\end{array}$ & Declared in $\mathbf{2 0 1 8}$ & Declared in 2019 \\
\hline Infrastructure & $\begin{array}{c}\text { traffic congestion, decreasing road and } \\
\text { parking space capacity }\end{array}$ & $\begin{array}{c}\text { Delays in road modernization (road } \\
\text { and rail transport), insufficient } \\
\text { infrastructure (linear and spot) }\end{array}$ \\
\hline
\end{tabular}

Technological

environment
Lack of funds for process automation, increase in IT spending with limited resources.
Declared in 2020

Railway infrastructure.

Development of e-commerce and decrease in demand for transport from distribution centers to stationary sales points, development of freight exchanges, new technologies requiring financial investments.

blockade of markets, nepotism, trade wars, the situation of German economy, low unemployment and rising wage expectations, exchange rate differences in international transport, rising labor costs, economic slowdown of EU and PL, Mobility

Package, rising transport costs,

Macroeconomic environment saturated labor market in the industry, uncertain value of PLN, higher risk of currency exchange rate fluctuations against USD and EUR, and even lower margins on foreign sales, changes related to retirement age, problems with city logistics, rising fuel prices, political situation in Poland, political situation in Europe (Russia vs. EU vs Turkey), political factors hampering trade with Russia and Ukraine

unfavorable legal regulations, EU regulations,

protectionism at the European level, introduction of minimum wages by successive EU member states, lack of reaction on the part of the Polish government to the problems of carriers, increasing bureaucracy,

Legal environment
Recession, decrease in consumption, increase in fiscal burdens on enterprises, greater connection between politics and business-negative impact, unstable political situation in Poland and in the world, high dependence of Poland on the macroeconomic situation in the world, increase in protectionism, competition from the Silk Road to the sea road, unstable situation on the sea freight market, decrease in the inflow of financial resources from EU funds.
Recession, economic crisis, decrease in production and consumption, increase in unemployment, inflation, decrease in liquidity, company bankruptcy, consolidation, isolationism, protectionism, restriction of free movement of goods across borders, decrease in international exchange, increase in environmental charges, road tolls, taxes, exchange rate

fluctuations, increase in energy prices, Brexit, lengthening of supply chains, increase in competition from TFL companies from the East (Russia, Ukraine, Belarus), high dependence of the economy on the European Union market, uncertain political situation, decrease in import from China.
Formal and legal obstacles imposed by Western European countries on Eastern European TFL companies, mobility package, legal restrictions related to the pandemic. formal and legal obstacles imposed by Western countries, protectionism of the "old EU" countries towards the "new EU" countries, interference in the Polish market of "third countries", changeability of Polish law,

limitations for Polish carriers in

Europe-MiLOG in Germany, Loi

Macron in France or recently in Italy.

administrative procedures; increas in fiscal burdens (taxes, costs of ship owner adaptation to new standards of sulfur content in marine fuel, increase in energy prices), lack of clear procedures when employing foreigners, restriction of access to city centers, regulations concerning environmental protection.

Shortage of skilled workers; shortage of drivers, warehouse workers; increased competition in the industry and outside the industry (Uber), the possibility of taking over the Polish TFL market by carriers from Russia, Belarus,

lack of drivers, lack of workforce, constant problem with obtaining qualified staff, both office and warehouse workers and drivers, technological changes-more solutions that ignore traditional Organizational environment
Ukraine, new business models (cost pressure, price pressure), increase in wages, interception by global shipping line organizations, taking over the competence of freight forwarders, self-service logistics introduced by global players in the online trading market

Delays in road modernization (road and rail transport), insufficient infrastructure (linear and spot).
Notable consolidation in the industry, acquisitions of smaller and weaker companies, increase in bankruptcies and bankruptcies in the TFL industry, lack of professional drivers, qualified employees (office, warehouses workers, also rail transport workers), increase in competition, decrease in liquidity among customers (payment deferrals), shorter supply chains, access to shipping containers (uneven geographical distribution), increase in costs, decrease in profitability, development of intermodal transport (displaces road transport)—change in the share of individual branches in freight transport, expansion of ship owner activities. 
The authors analyzed whether the companies that create the reports have better financial results than the others. However, no such relationship was found. The authors hypothesize that, in the long run, such a dependence could occur, but it will be revealed not necessarily through hard financial indicators, but through a lower employee retention rate, a higher level of job satisfaction (when examining employee satisfaction indicators), as well as more durable and transparent bonds with suppliers and customers. At the same time, it is worth adding that young people are more likely to apply to companies that emphasize sustainable development in their mission. The opportunity to pursue their own passions at work, one of which is participation in voluntary projects, is becoming more and more valuable from the youngest generation $\mathrm{Z}$ perspective.

However, changes to the above-mentioned areas can only take place if the sustainable development report is actually an element of the company's operating strategy, not only a declaration, as was the case with international corporations in the USA in 2019 [33].

Dominating pro-ecological activities among the surveyed companies from the TFL sector include the replacement of rolling stock with the less-polluting environmental one (almost $80 \%$ of indications), as well as the consolidation of loads, training of drivers, and increasing intermodal and rail transport. Among the measures taken to reduce waste, there are, e.g., reduction of printing ( $95 \%$ of indications), use of ecological packaging (approx. 50\%), segregation of waste and rubbish (95\%). Here, the companies with foreign and mixed capital are in the lead too. Almost $60 \%$ of companies conduct training in the field of ecology. At the same time, activities are undertaken for the benefit of the local community, mainly consisting in cleaning or tidying up areas near the headquarters of the companies $(26 \%)$ and others $(46 \%)$. Other activities include humanitarian actions, cooperation with foundations, local schools (donating equipment, education in local schools and kindergartens, workshops), dialogue sessions, and social campaigns, sponsoring local sports clubs.

As for the share of women in managerial positions among managers, this ratio is $41 \%$ for all companies. The index is slightly higher among companies that prepare social reports (but do not publish them) - $46 \%$. On the other hand, the share of women as managers in smaller companies with revenues ranging from PLN 10 to 49 million per year (51\%), is definitely above average. This may indicate greater flexibility in adapting to the market among smaller companies, as well as in taking up new challenges by female managers in those companies whose owners are also women.

The aim of the present analysis, based on surveys, was to show to what extent the challenges and threats presented in the open (descriptive) part of the survey relate to the issue of sustainable development, which is considered in the block devoted to the above subject. As in the case of the tables, both the persistence of specific challenges and threats, as well as changes in the above-mentioned area, were shown. For comparison, it was decided to present the results of the 2020 survey, showing only the trend. The awareness of companies from the TFL industry in this regard is growing, but still no fundamental changes are visible. Perhaps such changes will take place next year, when business models are forced to adapt, due to the pandemic.

\section{Conclusions}

The present results of research, covering the period between 2018 and 2020, on challenges and threats anticipated for the next two years, could indicate that the TFL industry is facing many difficulties. The threats mentioned so far, such as the lack of specialized staff, increased costs, or the introduction of the Mobility Package, have expanded in 2020, by concerns about the impact of the coronavirus pandemic on the entire global economy and on the industry itself. As a result, factors related to the macroeconomic situation were mentioned in 2020 before the area of intra-industry changes and fear of unfavorable legal solutions. 
Owing to the uncertain situation, companies from the TFL sector will look with concern to the coming months. Uncertain about tomorrow, what costs and problems they will face, they are cautious about investments.

A positive aspect of the crisis is that it encourages innovative and alternative solutions. The coronavirus is accelerating the development of e-commerce in Poland, which is clearly visible in experts' opinions. According to many of them, after the pandemic is over, there will be a greater demand for international transport services, where Polish entrepreneurs are still the leader. This is an opportunity to sustain the plans for expansion to international markets. However, the condition for maintaining competitiveness in road transport and logistics is the implementation of modern technologies, which is associated with specific financial expenditures.

Additionally, market disruption caused by the coronavirus pandemic and the upcoming new regulations related to the Mobility Package will, in the opinion of the respondents, accelerate the consolidation of the TFL market in Poland. Depending on the size of the company, its market position, and the condition after the pandemic, this process is perceived as an opportunity but also a threat. Consolidation will accelerate digitalization and broadly understood automation of business processes. This in turn will directly translate into financial efficiency. TFL companies, which are already working on the implementation of new technologies, will gain a competitive advantage.

In the context of the challenges and threats predicted by managers in 2018, the authors have undertaken an analysis to determine to what extent the presented forecasts materialized in 2020. When it comes to challenges, the mobility package was implemented in 2020 and the United Kingdom left the European Union (EU), although the terms of the agreement with the EU are not yet fully known. The share of intermodal transport has slightly increased while on the other hand, cargo rail transport has regressed in relation to 2018. The situation is quite complex and does not apply to all countries, but on average there is a noticeable decrease in the share of freight mass transported by the rail transport. The challenges related to the infrastructure improvement have largely materialized with evidence of the growing importance of new technologies. In turn, the threats related to the deficit of drivers are still valid. As a result, some companies are introducing campaigns promoting the profession of truck driver among women. Similarly, the shortage of employees is visible among warehouse workers. In 2020, protectionist measures intensified, and the political situation worsened. However, the factors related to the development of technology and the rapidly advancing digitization are primarily the result of the pandemic and similar to the relocation of production plants closer to the outlet, although not a subject of discussion with managers in 2018. Thus, 2020 is unusual in terms of managers' forecasts included in surveyed questionnaire. Nobody was able to predict the pandemic that changed the world's market in such a drastic way. However, as can be seen from the analysis, some forecasts, especially regarding external factors-legal and macroeconomic - have materialized. The breakdown of supply chains as a result of the introduced lockdowns caused quite unexpected changes in both the flow of loads and the flow of load directions. These changes have not been anticipated in advance. As a result, the carbon footprint has also decreased. However, these are not changes consciously introduced by enterprises as a part of their action strategy, but related to the epidemiological restrictions introduced by individual countries locally. Therefore, they could be impermanent.

Author Contributions: Conceptualization, H.B. and A.B.; methodology, H.B.; software, H.B. and A.B.; validation, H.B. and A.B.; formal analysis, H.B.; investigation, H.B.; resources, H.B.; data curation, H.B. and A.B.; writing-original draft preparation, H.B. and A.B.; writing-review and editing, H.B. and A.B.; visualization, H.B. and A.B.; supervision, A.B.; project administration, A.B.; funding acquisition, H.B. and A.B. All authors have read and agreed to the published version of the manuscript.

Funding: This work was partially supported by the Ministry of Science and Higher Education (MNiSW, Poland) core funding for statutory R\&D activities. 
Institutional Review Board Statement: Not applicable.

Informed Consent Statement: Not applicable.

Data Availability Statement: The data presented in this study are available in https:/ /g.gazetaprawna. pl/p/_wspolne/pliki/4552000/4552633-tabeletsl-2020.pdf.

Conflicts of Interest: The authors declare no conflict of interest.

\section{References}

1. Eurostat. GDP Down by 3.8\% in the Euro Area and by 3.5\% in the EU; Eurostat: Luxembourg, 2017.

2. Eurostat. Eurostat Preliminary Flash Estimate for the Second Quarter of 2020; Eurostat: Luxembourg, 2020; pp. 1-3. Available online: https:/ / ec.europa.eu/eurostat/documents/2995521/11156775/2-31072020-BP-EN.pdf/cbe7522c-ebfa-ef08-be60-b1c9 d1bd385b (accessed on 17 October 2020).

3. Real Gross Domestic Product Growth Rate Forecasts in Selected European Countries from 2020 to 2021 . Available online: https:/ / www.statista.com/statistics/1102546/coronavirus-european-gdp-growth (accessed on 17 October 2020).

4. Sternberg, H.S.; Hofmann, E.; Overstreet, R.E. Perils of road freight market deregulation: Cabotage in the European Union. Int. J. Logist. Manag. 2020, 31, 333-355. [CrossRef]

5. YingHui, L. COVID-19: The Nail in the Coffin of China's Belt and Road Initiative? Available online: https://thediplomat.com/20 20/09/covid-19-the-nail-in-the-coffin-of-chinas-belt-and-road-initiative (accessed on 17 October 2020).

6. Mazur, M.; Urban, G.; Wroński, M. Transport of the Future. Report on prospects for the development of road transport in Poland in 2020-2030; PwC: Warsaw, Poland, 2019.

7. $\quad$ Fechner, I.; Szyszka, G. (Eds.) Logistyka w Polsce. Raport 2017; Biblioteka Logistyka: Poznań, Poland, 2018.

8. Klimaszewska, E.; Rzymek, B. (Eds.) Transport_Wyniki Działalności w 2019 r.; Urząd Statystyczny w Szczecinie: Warsaw, Poland, 2020.

9. Mroczek, W. Spada Znaczenie Transportu Kolejowego dla Eksportu i Importu. Pociagi Przewożą 6,5 Razy Mniej Ładunków niż Ciężarówki. Available online: https://trans.info/pl/transport-kolejowy-traci-znaczenie-w-przewozach-dla-eksportu-i-importu198678\# (accessed on 18 October 2020).

10. Gopalakrishnan, R.; Alho, A.R.; Sakai, T.; Hara, Y.; Cheah, L.; Ben-Akiva, M. Assessing overnight parking infrastructure policies for commercial vehicles in cities using agent-based simulation. Sustainability 2020, 12, 2673. [CrossRef]

11. McLeod, S.; Curtis, C. Understanding and Planning for Freight Movement in Cities: Practices and Challenges. Plan. Pract. Res. 2020, 35, 201-219. [CrossRef]

12. Eshtehadi, R.; Demir, E.; Huang, Y. Solving the vehicle routing problem with multi-compartment vehicles for city logistics. Comput. Oper. Res. 2020, 115, 104859. [CrossRef]

13. Chandra, S.; Christiansen, M.; Fagerholt, K. Analysing the modal shift from road-based to coastal shipping-based distribution-A case study of outbound automotive logistics in India. Marit. Policy Manag. 2020, 47, 273-286. [CrossRef]

14. Wagener, N.; Aritua, B.; Zhu, T. LogForum. Sci. J. Logist. 2020, 16, 193-207.

15. Kumar, A.; Anbanandam, R. Evaluating the interrelationships among inhibitors to intermodal railroad freight transport in emerging economies: A multi-stakeholder perspective. Transp. Res. Part A Policy Pract. 2020, 132, 559-581. [CrossRef]

16. Ram, J.; Zhang, Z. Belt and road initiative (BRI) supply chain risks: Propositions and model development. Int. J. Logist. Manag. 2020, 31, 777-799. [CrossRef]

17. Nitsche, B. Decrypting the belt and road initiative: Barriers and development paths for global logistics networks. Sustainability 2020, 12, 9110. [CrossRef]

18. Ge, Y.; Dollar, D.; Yu, X. Institutions and participation in global value chains: Evidence from belt and road initiative. China Econ Rev. 2020, 61, 101447. [CrossRef]

19. Chan, H.K.; Dai, J.; Wang, X.; Lacka, E. Logistics and supply chain innovation in the context of the Belt and Road Initiative (BRI). Transp. Res. Part E Logist. Transp. Rev. 2019, 132, 51-56. [CrossRef]

20. Wang, X.; Wong, Y.D.; Li, K.X.; Yuen, K.F. Transport research under Belt and Road Initiative: Current trends and future research agenda. Transp. A Transp. Sci. 2020, 1-23. [CrossRef]

21. Beškovnik, B.; Golnar, M. Eliminating barriers for sustainable transport systems on maritime silk road and baltic-adriatic corridor under BRI. Sustainability 2020, 12, 7412. [CrossRef]

22. Nenni, M.E.; Sforza, A.; Sterle, C. Sustainability-based review of urban freight models. Soft Comput. 2019, 23, 2899-2909. [CrossRef]

23. Shareef, M.A.; Dwivedi, Y.K.; Kumar, V.; Mahmud, R.; Hughes, D.L.; Rana, N.P.; Kizgin, H. The inherent tensions within sustainable supply chains: A case study from Bangladesh. Prod. Plan. Control 2020, 31, 932-949. [CrossRef]

24. Ali, M.M.; Babai, M.Z.; Boylan, J.E.; Syntetos, A.A. Supply chain forecasting when information is not shared. Eur. J. Oper. Res. 2017, 260, 984-994. [CrossRef]

25. Nitsche, B.; Straube, F. Efficiently managing supply chain volatility-A management framework for the manufacturing industry. Procedia Manuf. 2020, 43, 320-327. [CrossRef]

26. Lim, S.F.W.T.; Jin, X.; Srai, J.S. Consumer-driven e-commerce: A literature review, design framework, and research agenda on last-mile logistics models. Int. J. Phys. Distrib. Logist. Manag. 2018, 48, 308-332. [CrossRef] 
27. Cardenas, I.; Borbon-Galvez, Y.; Verlinden, T.; Van de Voorde, E.; Vanelslander, T.; Dewulf, W. City logistics, urban goods distribution and last mile delivery and collection. Compet. Regul. Netw. Ind. 2017, 18, 22-43. [CrossRef]

28. Brdulak, H.M. W 2017 r. rynek TFL rósł dwa razy szybciej niż PKB w Polsce. Gaz. Prawna 2018, 118, D16-D17.

29. UN UNODC and the 2030 Agenda for Sustainable Development. Available online: https://www.unodc.org/unodc/aboutunodc/sustainable-development-goals/sdgs-index.html (accessed on 20 September 2020).

30. Brdulak, H.M. Wskaźniki Rosna w Prawie Wszystkich Kategoriach w Rankingu; Dziennik Gazeta Prawna: Warsaw, Poland, 2019.

31. Brdulak, H.M. Sytuacja Gospodarcza w Okresie Pandemii. Zmiany Architektury Łańcucha Dostaw; Dziennik Gazeta Prawna: Warsaw, Poland, 2020.

32. Brdulak, H.M. Droga do Zrównoważonego Rozwoju Miast z Poszanowaniem Prawa Wszystkich Mieszkańców do Dobrej Jakości Życia. Transport Jako Szansa $i$ Wyzwanie; United Natios Global Compact: Warsaw, Poland, 2018.

33. Stiglitz, J.E. Czy Kapitalizm Interesariuszy Naprawdę Wraca? Available online: https://krytykapolityczna.pl/swiat/brtpodpisuje-oswiadczenie-ale-nie-placi-podatkow/ (accessed on 23 September 2020). 